\title{
EFL Learners' Responses on the Use of Performance-based Assessment
}

\author{
Entika Fani Prastikawati \\ Universitas PGRI Semarang (Upgris), Semarang \\ zfanyprasti@gmail.com
}

Article History: Submitted 12 January 2018; Accepted 28 February 2018; Published 30 March 2018

\begin{abstract}
Assessment is an ongoing process of evaluating learners' ability or skill after process of teaching and learning. In English class, assessment also plays an important role. According to the facts found, assessment mostly used in English class is traditional assessment. English class needs more alternative assessments to set the goals of learning English. Curriculum 2013, which is used in Indonesia right now, emphasizes the use of authentic assessment, and performance - based assessment is to be a subset of authentic assessment. This article is trying to discuss the students' responsess on the use of performance-based assessment applied by the English teachers. This study applied descriptive qualitative research design. The subjects of this research were 30 Senior High School students. To collect the data needed, this study used observation and interview as the instrument. The observation was used to discover performance-based assessments which had already been applied by the English teachers in school. The result of the interview was interpreted to clarify the students' responsess on the use of performance-based assessment applied by the English teachers. Performance-based assessments which had already been applied were roleplays, writing sample, and retelling. From 6 classes, 3 classes (50\%) applied role-plays. Moreover, $2(33,3 \%)$ classes applied writing sample, and the rest applied retelling $(16,66 \%)$. It means that role-plays was performance-based assessment which was mostly applied by the English teachers. Furthermore, the students' responsess on the use of performance-based assessment was good. Almost of the 30 students considered that performance-based assessment can improve their English skills and confidence instead of traditional assessment. 24 of the 30 students also claimed that traditional assessment is still inadequate to activate their English skill. In short, $80 \%$ of 30 students gave a positive responsess on the use of performance-based assessment.
\end{abstract}

Keywords: assessment, performance-based assessment, English learning 


\begin{abstract}
ABSTRAK
Penilaian merupakan proses berkelanjutan dalam mengevaluasi kemampuan dan ketrampilan siswa setelah melalui proses belajar mengajar. Dalam pembelajaran bahasa Inggris di kelas, penilaian memiliki peran yang sangat penting. Berdasarkan fakta yang didapatkan, jenis penilaian yang digunakan dalam kelas bahasa Inggris masib menggunakan jenis penilaian tradisional. Padahal, pembelajaran bahasa Inggris di Kelas membutubkan lebih banyak jenis penilaian alternative untuk mencapai tujuan pembelajaran yang sesuai dengan kurikulum 2013 yang digunakan di Indonesia sekarang ini. Kurikulum tersebut menitikberatkan pada penggunaan penilaian autentik-penilaian berbasis unjuk kerja sebagai jenis penilaian utama yang digunakan. Artikel ini akan membahas mengenai respon siswa terbadap penggunaan penilaian berbasis unjuk kerja yang digunakan oleh guru. Desain penelitian ini adalah deskripitif kualitatif dengan subjek. 30 siswa. Instrumen pengambilan data yang digunakan adalah observasi dan interview. Observasi dilakukan untuk melihat penggunaan penilaian berbasis unjuk kerja yang digunakan guru, sedangkan interview digunakan untuk. menginterpretasi respon siswa terbadap penggunaan jenis penilaian berbasis unjuk. kerja yang telah digunakan oleh guru. Jenis penilaian berbasis unjuk. kerja yang digunakan guru antara lain bermain peran, menulis ulang, dan menceritakan kembali. Dari keenam kelas, 3 kelas menggunakan bermain peran (50\%). Selebihnya 2 kelas menggunakan menulis ulang (33,3\%) dan 1 kelas menggunakan jenis penilaian dengan menceritakan ulang $(16,66 \%)$. Hal tersebut menunjukan basil babwa bermain peran yang paling banyak. dgunakan oleh guru bahasa Inggris. Terlebih lagi, respon siswa baik. terhadap penilaian berbasis unjuk kerja yang digunakan oleb guru. Hamper 30 siswa menganggap babwa penilaian berbasis unjuk kerja dapat meningkatkan ketrampilan dan kepercayaan diri berbahasa Inggris mereka daripada penilaian tradisional. 24 siswa dari 30 siswa mengatakan bahwa penilaian tradisional masib kurang mampu untuk meningkatkan kemampuan berbahasa Inggris mereka. Kesimpulanya, 80\% dari 30 siswa telah memberikan respon positif terbadap penggunaan penilaian berbasis unjuk. kerja.
\end{abstract}

Kata kunci: penilaian, penilaian berbasis unjuk kerja, pembelajaran bahasa Inggris

\title{
INTRODUCTION
}

Teaching and learning process is an action necessary to accomplish a goal of education. It is the most powerful instrument of education to bring about desired improvement in the students. According to Fulcher and Davidson (2007:25), teachers usually understand a great deal about the knowledge, abilities and skills of the learners in their classroom without the need to resort to formal tests. Over periods of time they have the opportunity to observe learners participate in a wide range of activities and tasks. To measure whether the desired improvement has been achieved, it needs assessment. Assessment is an ongoing process of evaluating learners' 
ability or skill after process of teaching and learning. By assessment, learners can get feedback of what they have learnt and they are expected to be able to apply knowledge in their life. Therefore, an assessment should be meaningful and can be applied in learners' real life.

In English class, assessment also plays an important role. By assessment, English teachers are able to measure the goals of learning English. According to the facts found, assessment mostly used in English class is traditional assessment (Wiyaka, et all: 2013). Based on Brown (2004: 13), two of traditional assessment's characteristics are standardized exam and the use of multiple-choice format. Meanwhile, O'Malley and Valdez Pierce (1996: 2) state that multiple-choice tests is not authentic since they do not represent activities students typically perform in classrooms. Wiyaka, et al (2016:54) also says that multiple choice tests cannot capture what the students are able to do in terms of language use. Thus, traditional assessment may not be useful enough to learners' need because they are demanded to apply knowledge in their real life.

In accordance with the problem above, English class needs more alternative assessments to set the goals of learning English. It is supported by Permendikbud 66 (2013: 1), Curriculum 2013, which is used in Indonesia right now, emphasizes the use of authentic assessment. Mueller (2005: 2) explains that authentic assessment is a form of assessment in which students are asked to perform real-world tasks that demonstrates meaningful application of essential knowledge and skills. Moreover, O’Malley and Valdez Pierce (1996) taken by Brown (2004: 255) consider that performance - based assessment to be a subset of authentic assessment.

Now, Senior High Schools have already applied Curriculum 2013. It means that authentic assessments including performance-based assessments are supposed to have been applied. Abedi (2010) from Stanford Center for Opportunity Policy in Education writes an article about research entitled "Performance Assessment for English Language Learners". This research focuses on the effectiveness of performance assessment for English language learners to improve their academic performance.

The research findings state that performance assessments are a powerful alternative. They can engage English language learners in the assessment tasks and more comprehensively demonstrate their knowledge in content-based areas. Performance assessment also can contribute to the academic careers of students by informing instruction and supporting higher-quality teaching and learning. Such tasks are also instructional, allowing students to actively engage in worthwhile learning activities in the classroom. To add, research entitled "Performance and Portfolio 
Assessment for Language Minority Students" conducted by Valdez Pierce and J Michael O'Malley (1992) focuses on describing performance assessment procedures and a portfolio assessment framework for monitoring the language development of language minority students. The result shows to be able to effectively monitor the progress of language minority students, assessment needs to be conducted on an ongoing basis with procedures that promise to yield the most useful information for classroom instruction. While standardized achievement tests cannot provide this type of information, performance-based assessment can.

Therefore, it needs to find how is the students' responsess on the use of performance-based assessment to assess their achievement in learning English. This article is trying to discuss the students' responsess on the use of performance-based assessment applied by the English teachers.

\section{Authentic Assessment}

The term authentic assessment is well known in line with the implementation of curriculum 2013. Permendikbud 66 (2013: 1) declares that Curriculum 2013, which is used in Indonesia right now, emphasizes the use of authentic assessment. However, "the concept of authenticity has generated quite a ripple in ESL/EFL classrooms. Contrasting perspectives have emerged over the years in reaction to this concept" (Joy, 2011: 7). Wiggins (1993) taken by Muller (2005) explains authentic assessments are "engaging and worthy problems or questions of importance, in which students must use knowledge to fashion performances effectively and creatively. Muller (2005: 2) adds authentic assessment is a form of assessment in which students are asked to perform real-world tasks that demonstrate meaningful application of essential knowledge and skills. To add, Aksu (2012: 7) states that authentic assessment also emphasizes the importance of the teacher's professional judgment and commitment to enhance student learning. It guides the teaching and learning through the creation of various learning activities carried out by the students during the teaching and learning process which contains character values (Yunus, 2012: 174).

According to O'Malley and Valdez Pierce (1996: 4), authentic assessment includes:

\section{Performance-based assessment}

Performance-based assessment consists of any form of assessment in which the students construct a responsess orally or in writing. Moreover, it requires students to accomplish complex and significant tasks, while 
bringing to bear prior knowledge, recent learning and relevant skills to solve realistic or authentic problem.

\section{Portfolios}

Based on Valencia (1991) taken by O’Malley and ValdezPierce (1996: 5), portfolio assessment is a systematic collection of student work that is analyzed to show progress over time with regard to instructional objectives. One of the defining features of portfolio assessment is the involvement of students in selecting samples of their own work to show growth or learning over time.

\section{Students-self assessment}

Self-assessment is an important process for a students in learning. Aryadoust (2012: 1) states that it is a process by which students evaluate their own language competence. According to O'Malley and Valdez Pierce (1996: 5), self-assessment promotes direct involvement in learning and the integration of cognitive ability with motivation and attitude toward learning. It means that the students are given a chance to make some choices, select what learning activities and make a plan of learning. This directs the students to have a challenging activities when they are learning.

\section{Performance-Based Assessment}

Performance based assessment is as one of alternatives to measure students' achievement by asking them to perform their ability in real life situation. For example, to assess students' reading skill, retelling provides better measurement instead of answering multiple-choice because in a real life, students do not face multiple-choice after reading, but the possible action that they have to do is retelling what they have read. Thus, performance assessment is meaningful and can give experience for students that then they can apply in their real life.

Based on Hibbard (1996: 5) in Griffith (2012: 2), performance based assessment is an assessment that represents a set of strategies for the application of knowledge, skills, and work habits through the performance of tasks that are meaningful and engaging to students. This implies that performance based assessments are designed to more closely reflect and to emulate the context or conditions in which the learned knowledge or skill are actually applied. Stiggins (1992) has also defined this form of assessment under the name of performance assessment in this way: "performance assessments call upon the examinee to demonstrate specific skills and competencies, that is, to apply the skills and knowledge they have 
mastered". In addition, Palm (2008: 4) asserts performance assessment can be viewed as responsess-centered or simulation-centered. Responsesscentered definitions focus on the responsess format of the assessment, and simulation centered definitions focus on the observed student performance. It means assessments built up by tasks with any responsess format requiring student-constructed responsess are performance assessment. They require students to produce an answer of a question instead of selecting possible answers such as multiple-choice. Meanwhile, simulation-centered can be interpreted as assessments reflecting real life experience. In other words, performance based assessments require students to take part actively in the assessment.

O'Malley and Valdez Pierce (1996: 5) assert that some of the characteristics of performance-based assessment are as follow:

\section{Constructed Responsess}

Performance-based assessment requires students to construct a responsess, provide an expanded responsess, engage in a performance, or create a product.

\section{Higher-order Thinking}

In performance-based assessment, student typically uses higher levels of thinking in constructing responsesss to open-ended questions.

\section{Authenticity}

Tasks are meaningful, challenging, and engaging activities that mirror good instruction or other real-world contexts where the student is expected to perform.

\section{Integrative}

The tasks call for integration of language skills and, in some cases, for integration of knowledge and skills across content areas.

\section{Process and Product}

Procedures and strategies for deriving the correct responsess or for exploring multiple solutions to complex tasks are often assessed as well (as or sometimes instead of) the product or the "correct" answer. 


\section{Depth Versus Breadth}

Performance assessments provide information in depth about a student's skills or mastery as contrasted with the breadth of coverage more typical of multiple-choice tests.

Meanwhile, O’Malley and Valdez Pierce (1996: 5) give the types of performance-based assessment as the following:

Table 1:

Types of Performance-Based Assessment

\begin{tabular}{|c|c|c|}
\hline Assessment & Description & Advantages \\
\hline Oral interview & $\begin{array}{l}\text { Teacher asks students } \\
\text { questions about personal } \\
\text { background, activities, } \\
\text { reading and interest }\end{array}$ & $\begin{array}{l}\text { - Informal and relaxed } \\
\text { context } \\
\text { - Conducted over successive } \\
\text { days with each student } \\
\text { - Record observations on an } \\
\text { interview guide }\end{array}$ \\
\hline $\begin{array}{l}\text { Story or text } \\
\text { retelling }\end{array}$ & $\begin{array}{l}\text { Students retell main ideas } \\
\text { or selected details of text } \\
\text { experienced through } \\
\text { listening or reading }\end{array}$ & $\begin{array}{l}\text { - Student produces oral } \\
\text { report } \\
\text { - Can be scored on content } \\
\text { or language components } \\
\text { - Scored with rubric or } \\
\text { rating scale } \\
\text { - Can determine reading } \\
\text { comprehension, reading } \\
\text { strategies }\end{array}$ \\
\hline Writing sample & $\begin{array}{l}\text { Students generate } \\
\text { narrative, expository, } \\
\text { persuasive or reference } \\
\text { paper }\end{array}$ & $\begin{array}{l}\text { - Student produces written } \\
\text { document } \\
\text { - Can be scored on content } \\
\text { or language components } \\
\text { - Scored with rubric or } \\
\text { rating scale } \\
\text { - Can determine writing } \\
\text { processes }\end{array}$ \\
\hline $\begin{array}{l}\text { Projects or } \\
\text { exhibitions }\end{array}$ & $\begin{array}{l}\text { Students complete project } \\
\text { in content area, working } \\
\text { individually or in pairs }\end{array}$ & $\begin{array}{l}\text { - Students make formal } \\
\text { presentation, written } \\
\text { report, or both } \\
\text { - Can observe oral and } \\
\text { written products and } \\
\text { thinking skills } \\
\text { - Scored with rubric or } \\
\text { rating scale }\end{array}$ \\
\hline Experiments / & Students complete & - Students make oral \\
\hline
\end{tabular}




\begin{tabular}{|c|c|c|}
\hline demonstrations & $\begin{array}{l}\text { experiment or } \\
\text { demonstrate use of } \\
\text { materials }\end{array}$ & $\begin{array}{l}\text { presentation, written } \\
\text { report, or both } \\
\text { - Can observe oral and } \\
\text { written products and } \\
\text { thinking skills } \\
\text { - Scored with rubric or } \\
\text { rating scale }\end{array}$ \\
\hline $\begin{array}{l}\text { Constructed- } \\
\text { responsess item }\end{array}$ & $\begin{array}{l}\text { Students respond in } \\
\text { writing to open-ended } \\
\text { questions }\end{array}$ & $\begin{array}{l}\text { - Student produces written } \\
\text { report } \\
\text { - Usually scored on } \\
\text { substantive information } \\
\text { and thinking skills } \\
\text { - Scored with rubric or } \\
\text { rating scale }\end{array}$ \\
\hline
\end{tabular}

\section{METHOD}

Since the objective of this study is to find out the students' responsesss on the use of performance-based assessment applied by the English teachers, this study applied descriptive qualitative research design. The subjects of this research were 30 Senior High School students. To collect the data needed, this study used observation and interview as the instrument. The interview would be open interview which explore the students's responsesss on the use of performance-based assessment. The observation was used to discover performance-based assessments which had already been applied by the English teachers in school. The result of the interview was interpreted to clarify the students' responsess on the use of performance-based assessment applied by the English teachers.

\section{FINDINGS AND DISCUSSION}

This study was conducted to find out the students' responsesss on the use of performance-based assessment. The data were gained by doing an observation and interview. The observation was conducted in order to find out performance-based assessments which had already been applied by the English teachers in school. These observation was done in 6 classes, and from the 6 classes the researcher took the students who were as the subject. There were 5 students from each class, so the amount of the subject was 30 students.

The first step of the research was conducting the observation. From the observation, the data were obtained as clearly described in the following chart: 


\section{Graphic 1:}

Performance-based Assessments which had already been Applied by the English Teachers in School

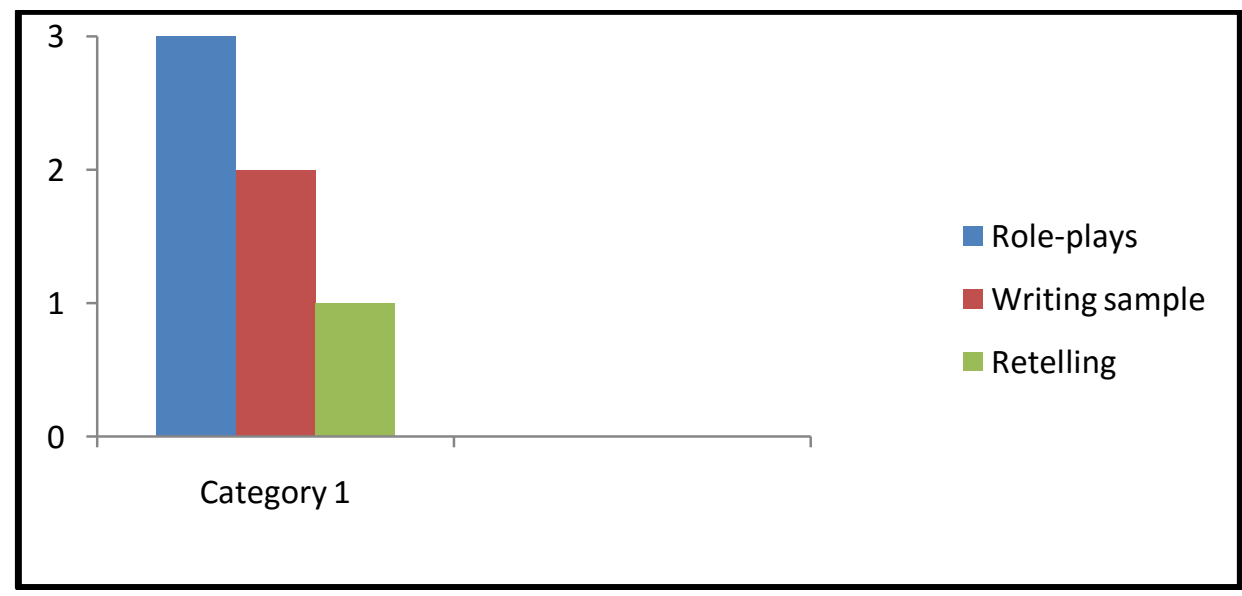

The chart above shows that the types of performance-based assessment which had already been applied by the English teachers were role-plays, writing sample, and retelling. From 6 classes, 3 classes applied role-plays. 2 of 6 classes applied writing sample, and the rest, which was only 1 class, applied retelling. In other words, role-plays was performancebased assessment which was mostly applied by the English teachers in school.

According to the data above, the interview was conducted to find out how is the studens' responsess on the use of performance-based assessment applied. It is clearly defined in the following chart.

Graphic 2:

The Students' Responsess on the Use of Performance-Based Assessment and Traditional Assessment

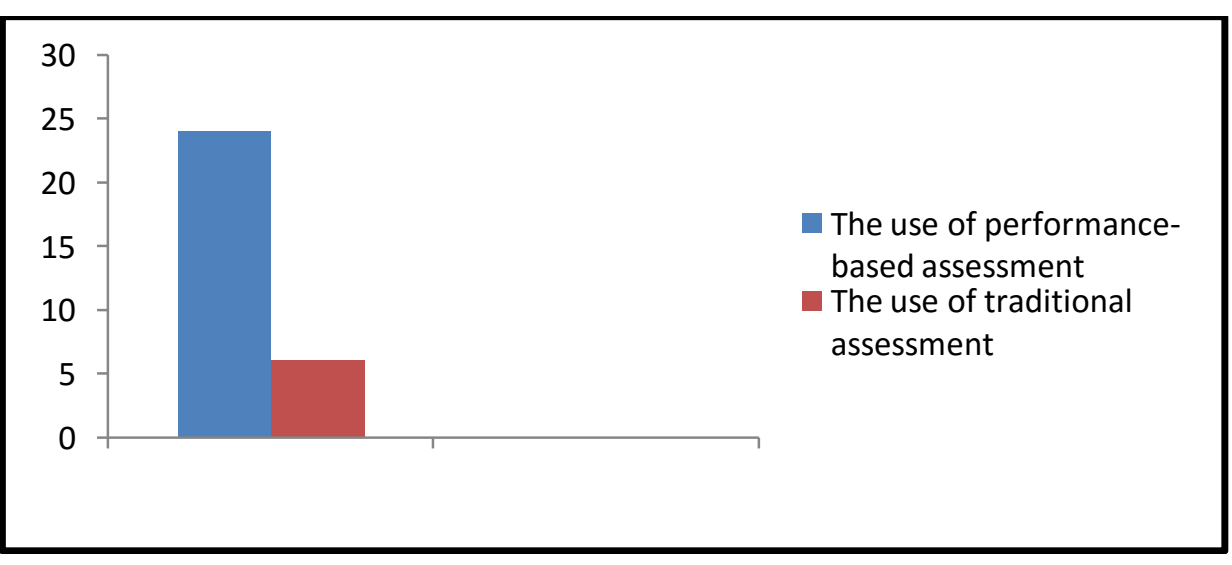


From the interview done, the data found is that from 30 students, there are 24 students considered that performance-based assessment can improve their English skills. Moreover, they are interested in performancebased assessment. It can be seen from the question in which their answers show that they expect the teacher applies performance-based assessment to assess them. Meanwhile, from 30 students, there are only 6 students who are interested in traditional assessment since they regard that traditional assessment is easier that performance-based assessment. They also regard that traditional assessment is not time-consuming to answer.

The chart showed that $24(80 \%)$ of the 30 students gave a positive responsess on the use of performance-based assessment. From the question about what the students' opinion on the use of performance-based assessment. 24 of the 30 students were interested in practicing their English skill, and they were happy since they were not demanded to answer correctly and they regard that performance-based assessment can improve their confidence.

Blaz (2001) cited by Griffith and Lim (2012: 3) states that performance-based assessments have several benefits, one of which is that performance-based assessment can increase students' confidence. It is accordance with the students' responsess that performance-based assessment can increase their confidence. Moreover, in the next question "In your opinion, could performance-based assessment improve your English skills? Why?" 24 of the 30 students considered that performancebased assessment could improve their English skills.

Meanwhile, there was only $6(20 \%)$ student who was doubtful that performance-based assessments could improve their English skills. Furthermore, those 6 students regard that performance-based assessment is more difficult than traditional assessment. However, it was argued by the 24 students who claimed that although traditional assessment is still not enough to activate their English skills. Those 6 students also prefer doing multiple choice to practicing their English skill. According to Smaldino et al (2000) cited by Dikli (2003: 15), traditional assessments often focus on learner's ability of memorization and recall, which are lower level of cognition skills.

All in all, the students' responsess on the use of performance-based assessments applied by the English teachers was good instead of the use of traditional assessment since they considered that traditional assessments was inadequate to fill their academic needs'. 


\section{CONCLUSION}

Based on the discussion of the research findings above, it can be concluded that performance-based assessments which had already been applied were role-plays, writing sample, and retelling. From 6 classes, 3 classes (50\%) applied role-plays. Moreover, 2 (33,3\%) classes applied writing sample, and the rest applied retelling. It means that role-plays was performance-based assessment which was mostly applied by the English teachers.

Furthermore, the students' responsess on the use of performancebased assessment was good. Almost of the 30 students considered that performance-based assessment can improve their English skills and confidence instead of traditional assessment. 24 of the 30 students also claimed that traditional assessment is still inadequate to activate their English skill. In short, $80 \%$ of 30 students gave a positive responsess on the use of performance-based assessment.

\section{REFERENCES}

Abedi, Jamal. 2010. Performance Assessment for English Language Learners. California: Stanford Center. Avalaible on https://edpolicy.stanford.edu/sites/default/files/events/materials/ 2011-06-linked-learning-performance-based-assessment.pdf (accessed 24 october 2015).

Aksu Atac, B. 2012. Foreign Language Teacher's Attitude toward Authentic Assessment in Language Teaching. The Journal of Language and Linguistic Studies, Vol. 8 No. 2, pp. 7-19.

Aryadoust, Vahid. 2012. Reliability of Second Language Listening Assessments: Implications for Pedagogy. ELTWorld, Vol. 4, pp. 116.

Brown, H. D. 2004. LANGUAGE ASSESSMENT; Principles and Classroom Practices. USA: Longman.

Dikli, Semire. 2003. Assessment at a distance: Traditional vs. Alternative Assessments, Vol. 2, ISSN 1303-6521.

Fulcher, Glen and Fred Davidson. 2007. Language Testing and Assessment. New York: Routledge.

Griffith, W. I. 2012. Performance Based Assessment, Vol. 36 No. 1. Taken from http://www.mextesol.net/journal/index.php?page=journal\&id arti cle $=108$. (accessed 4 Nov 2015).

Joy, J. J. L. 2011. The Duality of Authenticity in ELT. The Journal of Language and Linguistic Studies, Vol. 7 No. 2, pp. 7-23. 
Ministry of Education and Culture. 2013. PERATURAN MENTERI PENDIDIKAN DAN KEBUDAYAAN REPUBLIK INDONESIA NOMOR 66 TAHUN 2013. Jakarta: Unplished.

Mueller, Jon. 2005. The Authentic Assessment Toolbox: Enhancing Student Learning through Online Faculty Development, Vol. 1 No. 1. Avalaible on http://www.google.com/vol1_no1_mueller_001.pdf (accessed 5 Dec 2015).

Mueller, Jon. 2012. Authentic Assessment Toolbox. Avalaible om http://jfmueller.faculty.noctrl.edu/toolbox.whydoit.htm (accessed 5 December 2015).

O’Malley, J. M \& P. Valdez Pierce. 1996. Authentic Assessment for English Language Language Learners. USA: Longman.

Palm, Torulf. 2008. Performance Assessment and Authentic Assessment: A Conceptual Analysis of Literature, Vol. 13 No. 4. ISSN 1531-7714. Taken from http://-pareonline-net/-getvn.asp-?v=13\&n=4.pdf. (accessed 17 March 2016).

Stiggins, R.(1992). High quality classroom assessment: What does it really mean? NCME Instructional Topics in Educational Measurement Series,Module 12, Summer.

Valdes Pierce, L. \& J. M, O’Malley. 1992. Performance and Portfolio Assessment for Language Minority Students, No 9. Available on https://www.google.com/Academics-Education-PerfAssessmentV2-1.pdf (accessed 24 0ctober 2015).

Wiyaka, et.al. 2016. Alternative Assessments for Reading in Senior High Schools: A Guide for Classroom Practices. CELT (Culture, English Language \& Literature), Vol. 6 No. 1, pp. 49-66.

Yunus, Abidin. 2012. Model Penilaian Otentik dalam Pembelajaran Membaca Pemahaman Berorientasi Pendidikan Karakter. Jurnal Pendidikan Karakter Tabun 2, No. 2, pp. 164-178. 